\title{
Determinants of Central Eastern European Banks' Adequacy Risk
}

\author{
Jowita Grzelak*
}

Banks in their operations are exposed to many factors that may have a negative impact on their functioning. Fears of negative consequences of the risk that could lead to the bank's bankruptcy were compounded after the collapse of Lehman Brothers in 2008. The Lehman Brothers example shows how important the issues of supervision, bank management and risk management are. The purpose of this article was to identify the main determinants that affect the capital adequacy risk of commercial banks from Central and Eastern Europe. This research seems to be significant due to the fact that a long-term loss of bank solvency may result in its bankruptcy. In this article, the solvency risk is represented by the capital Tier1 ratio. For the examined variables, which are suspected to have a statistically significant impact on the dependent variable, the following were selected: the size of the bank (natural logarithm of the value of assets), the ratio of equity to total assets, the ratio of loan allowances to total loans, the ratio of loans to total assets, the ratio of loans to non-working assets, total return on equity, the ratio of liquid assets to total assets and the ratio of loans to deposits.

Keywords: commercial bank, CEE, Tier I, capital adequacy, ratio, equity, panel data.

Submitted: 14.04.19 | Accepted: 20.05.19

\section{Determinanty ryzyka adekwatności kapitałowej banków Europy Środkowo-Wschodniej}

Banki w swej działalności narażone sa na wiele czynników, które moga mieć negatywny wptyw na ich funkcjonowanie. Obawy przed negatywnymi skutkami ryzyka, które może doprowadzić do upadtości banku, spotegowane zostaty po upadku banku Lehman Brothers w 2008 roku. Przyktad Lehman Brothers pokazuje, jak istotne sq kwestie nadzoru, zarzadzania bankiem oraz zarzadzania ryzykiem. Celem niniejszego artykułu byto zidentyfikowanie głównych determinant, które maja wplyw na ryzyko adekwatności kapitałowej banków komercyjnych z Europy Środkowo-Wschodniej. Badanie to wydaje się być istotne, ponieważ dtugotrwała utrata wyptacalności banku, może w konsekwencji prowadzić do jego upadtości. W niniejszym artykule ryzyko wyptacalności reprezentowane jest przez wspótczynnik kapitału Tier 1. Do badanych zmiennych, które podejrzewa się, że moga wptywać istotnie statystycznie na zmienna zależna wybrano: rozmiar banku (logarytm naturalny wartości aktywów), stosunek kapitatów do sumy aktywów, stosunek odpisów kredytowych to sumy udzielonych kredytów, stosunek udzielonych kredytów do sumy aktywów, udziat kredytów niepracujących w sumie aktywów, stopę zwrotu z kapitałów wtasnych, stosunek aktywów plynnych do sumy aktywów oraz stosunek udzielonych kredytów do depozytów.

\footnotetext{
Jowita Grzelak - mgr, Faculty of Management, University of Warsaw, Poland. https://orcid.org/00000002-6772-1019.

Correspondence address: Faculty of Management, University of Warsaw, 1/3 Szturmowa Street, 02-678 Warsaw, Poland.
} 
Słowa kluczowe: bank komercyjny, CEE, Tier 1, adekwatność kapitałowa, wskaźnik, dane panelowe.

Nadesłany: 14.04.19 | Zaakceptowany do druku: 20.05.19

JEL: G2

The main aim of the article is to identify financial indicators that determine the level of the adequacy risk in commercial banks in Central and Eastern Europe. The problem of capital adequacy and solvency of a bank is often associated with the risk of bankruptcy. By bankruptcy one should understand the situation when a bank loses its solvency capability. Due to the specificity of the activities of banks, which are called public trust institutions, dealing with them in the case of a risk of bankruptcy is completely different than in the case of other firms. Due to the fact that commercial banks are responsible for other people's money, they became the focus of the Basel Committee, which primarily regulates capital adequacy issues in commercial banks.

The commercial bank's capital adequacy in this paper is represented by the Tier I ratio which reflects the ratio of Tier 1 Capital at the end of the fiscal interim to Total Risk-Weighted Assets for the same period and is expressed as a percentage. Tier 1 Capital, also known as Core Capital, is defined as the sum of common stockholders' equity, certain qualifying issues of preferred stock and minority interest, less goodwill, intangible assets, investments in certain subsidiaries and other adjustments (Thomson Reuters, 2019).

This study uses microeconomic determinants connected with the financial indicators. The analysis was made using panel data, covering quarterly data from the beginning of 2007 to the end of 2017 for 202 banks from 16 countries of Central and Eastern Europe. The author assumed the hypothesis that all financial indicators which are a measure of a bank's risk are statistically significant and have an impact on commercial banks' capital adequacy represented by the Tier I ratio. In this paper, 8 variables were examined which represented the size of the bank's activity (SIZE - the natural logarithm of total assets), the importance of equity (EQUITY - the ratio of equity to total assets), credit risk (LOANCOSTS - allowances to total loans, LOANS - loans to total assets), quality of loans portfolio (NPL - non-performing loans to total loans), profitability (ROE - return on equity ratio) and liquidity (LIQUIDITY - liquid assets to total assets, LTD - loans to deposits ratio). The study showed that there is a statistically significant relationship between the Tier I ratio and 4 variables (ratio of equity to total assets, loans to total assets, return on equity ratio, non-performing loans to total loans) and 4 indicators are statistically insignificant. As far as the author knows, no similar analyses were done for Central Eastern European countries.

\section{Introduction}

Just as everyone of us is afraid of the various types of risks, banks are exposed to a variety of factors throughout their operations that may have a negative impact on their performance and the results they achieve. The fear of the negative impact of risk, which in the worst scenario can lead to the bank's bankruptcy, has intensified in recent years after the collapse of the Lehman Brothers investment bank in 2008 (Thlon, 2008). This fact is a part of the history of finance and is often referred to as the "beginning of the global financial crisis of 2008". The case study of Lehman Brothers shows how important the issues of financial system supervision, bank management, creating financial instruments and risk management are. It showed how enormous an impact may be exerted by the collapse of one significant financial institution on other from the rest of the world.

The necessity of regulating the banking activity was already noted by Ricardo, a classical economist who explained it by the fact that banks are institutions that use other people's money in their operations. The Basle Committee, which is the council of financial and banking experts, and its recommendations have proved how important a role in banking is played by 
risk management. Although its recommendations and guidelines are not strictly binding legal regulations, many countries decide to use them (Źółtkowski, 2007). The Basel Committee recommendations are an initiative that intends to integrate and consolidate supervisory activities over banks, but also other financial institutions that in the twentieth century have become a form of huge financial corporations. In the face of anxiety over their collapse, the role of appropriate preventive behaviors and constant monitoring of the financial situation is underlined, which is the subject of supervisory Basel regulations (Nieborak, 2001).

In the face of the need to change and repair the previous ones, the Basel Committee has published another recommendation after the New Basel Capital Agreement, called Basel III, which was included in the Basel III document: A global regulatory framework for more resilient banks and banking systems (BCBS, 2010). The main changes mainly concerned the clarification of all categories of regulatory capital in banks and the introduction of two capital buffers - countercyclical and protective (Małecki, 2014). Basel III modified the structure and quality of bank capital - significantly strengthened the importance of Tier I funds. In the Tier I, core capital (CET I) was determined, consisting of (Iwanicz-Drozdowska, 2017):

- ordinary shares issued by the bank,

- reserve capital,

- retained earnings,

- the issue premium originating from the issue of financial instruments which are classified as Common Equity Tier I,

- general banking risk fund.

The size of the required core funds (CET 1) was to increase from $2 \%$ to $4.5 \%$. In turn, the volume of core funds (Tier I) was to increase from previously required $4 \%$ to $6 \%$. The remaining $2 \%$, to maintain the $8 \%$ solvency ratio, could be covered by Tier II capital - the additional equity (Sikorzewski, 2011).

\section{Literature Review}

The problem of the impact of individual financial indicators on the capital adequacy ratio and the bankruptcy risk has been addressed by many researchers. This phenomenon is often studied in relation to the banks of a specific country. This article aims to detail the impact of financial indicators on the Tier 1 capital ratio in relation to Central and Eastern European banks.

The author has studied a few papers which focused on investigating the main determinants of capital adequacy ratio in specific countries. Abusharba, Triyuwono, Ismail, Rahman (2013) investigated whether the ratios of banks affect the capital adequacy requirements of Indonesian Islamic banks. Their research focused on profitability ratios, asset quality, liquidity, financial leverage and operational efficiency. The article revealed that ROA has a positive relationship with the capital adequacy ratio, which indicates that as profits increase, banks may be more motivated to protect the capital of their owners. It was also revealed that liquidity has a positive impact on the capital adequacy ratio of banks, which shows that banks with a good level of liquidity tend to improve the banks' capital. It was also revealed that bad financing has a negative relationship with the capital adequacy ratio, which meant that higher bad loans would depreciate the value of banks' capital, and banks may be more exposed to credit risk. On the other hand, this study showed that the structure of deposits and operational efficiency do not affect capital adequacy of Indonesian banks. Shingjerji and Hyseni (2015) tried to find the relationship between some banking ratios such as: profitability indicators, credit risk, liquidity risk, leverage, bank size and the capital adequacy ratio in the Albanian commercial banks. The research brought the following conclusions that the ROE and ROA have no impact on the capital adequacy ratio; the NPL ratio has a negative impact, which means that banks with higher credit risk have lower capitals; the LTD ratio has a negative impact on the capital adequacy ratio, which means that banks with higher liquidity risk tend to have lower capitals. The equity multiplier has a negative impact meaning that banks with a high leverage generally have a lower capital adequacy ratio. The bank size has a positive impact on the capital adequacy ratio, which means that larger banks have higher capital adequacy ratios. Klepczarek (2015) examined the factors impacting the CET1 ratio of banks assessed by the European Banking Authority The research showed a negative impact of the ROA ratio and a positive 
impact of the ROE ratio, a negative correlation between bank adequacy and the deposits to non-equity liabilities ratio. That can mean that decreasing the amount of core capital with an increase of the share of deposits in the liabilities structure may be a result of the deposit guarantee system. The analysis does not confirm the impact of profitability ratios and the inflation rate on capital adequacy. Risk-weighted assets to total assets negatively impact the CAR1 ratio, which confirms the difference in the risk perception among regulatory authorities and bank managers. It has been found that more loans in total assets implicate a more cautious structure of the bank's capital. Banks expanding their lending activities strengthen their source of funding by increasing their core capital. Dreca (2013) presented how the capital adequacy ratio is influenced by some ratios. Selected variables aimed to explain the determinants of the capital adequacy ratio in Bosnian banks. The author indicated variables such as: size of a bank (SIZE), ratio of deposits to total assets (DEP), ratio of loans to total assets (LOA), ROA, ROE and leverage (LEV) which have a significant effect on CAR. On the other hand, loan loss reserves (LLR) and the ratio of net interest income to total assets (NIM) do not appear to have a significant effect on CAR. Variables SIZE, DEP, LOA and ROA have a negative effect on CAR, while variables LLR, ROE, NIM and LEV are positively related with CAR. All variables except LOA and ROA have expected signs. Ahmad, Arfiff and Skully (2009) showed a new approach to determining factors that have an impact on bank capital ratios among commercial banks in developing Asian economies. The results of the study suggest a strong positive relationship between the behavior of regulatory capital and the behavior of the bank's management. Two risk variables: non-performing loans and a risk index (ratio of all liquid assets to total deposits) show a positive relationship between bank capital and risk taking. The size of the bank turned out to be a statistically non-significant variable which negatively affected capital adequacy. Lopez, Iturriiaga and Sanz (2010) raised the issue of developing a model of neural networks to investigate the bankruptcy of American banks, taking into account the specificity of the recent financial crisis. By combining multi-layered insights and self- organizing maps, the authors wanted to provide a tool that would estimate the likelihood of threats up to three years before the bankruptcy occurs. Based on data from the Federal Deposit Insurance Corporation in the years 2002-2012, the results of the analysis showed that bankrupt banks are more concentrated on real estate loans, as indicated by the fact that they have more reserves on this account. Their situation is partly caused by risky expansion, which results in lower capital and smaller interest income. After developing the profile of troubled banks, the developed model was used to detect failures and was a tool for assessing banking risk in the short, medium and long term using the data of banks that went bankrupt from May 2012 to December 2013 in the US. This model can detect $96.15 \%$ of failures in the period considered and outperforms traditional bankruptcy forecast models. Cox and Wang (2014) presented an analysis of the bankruptcy of United States banks during the financial crisis of 2008-2010. The researchers applied the discriminant analysis and the test of uniqueness of medium financial variables to examine banks that continued their activity and bankrupt banks. The best-case model for potential bankruptcy included the following variables: mortgage loans, growth rates, share balance, bank portfolio size, loan loss provisions, non-performing loans, net charges and property taken over. It was considered that the reason for the bankruptcy of banks is a higher proportion (relative to banks continuing operations) of the value of bad mortgage loans and other non-performing debts.

Risks related to the operation of commercial banks are reflected in their credit ratings. Hau, Langfield and MarquesIbanez (2012) analyzed the quality of credit ratings awarded by the three largest rating agencies. Bank ratings are interpreted by the authors as relative creditworthiness ratings and based on them they define new order numbers of rating errors based on the expected bankruptcy frequency of banks. The results of the study suggest that large banks receive more positive ratings, especially from those agencies for which they provide securitization services. These distortions of competition are important from an economic point of view and contribute to the consolidation of "too big to fail" banks. The authors also showed that 
the different risk weights recommended by the Basel agreements for investment grade banks do not have a material relationship with the probability of bankruptcy of banks. Belotti, Matousek and Stewart (2011) proposed the possibility of forecasting international banks' ratings. The research results suggest that the ratings given to banks reflect their financial situation, assessment time and country of origin. The study showed that banks with higher capitals, larger assets and higher ROA ratios are assigned higher ratings. Moreover, if the bank's liquidity increased two periods ago, it has an impact on improving the rating. In turn, if the operating expense ratio in relation to operating income is growing and the date of the assessment is relatively recent, the bank's ratings fall. The research also proved that the ratio of net operating income to the value of total assets has a negative impact on banks' ratings. In turn, the country of origin of the bank has a strong, proven impact on its rating. Hassan and Barrella (2013) showed that only a small number of accounting variables, i.e. the size of the bank, liquidity and efficiency are strongly related to banks' credit ratings. The model constructed by the authors can correctly assign creditworthiness to about $74-78 \%$ of banks from the 2002-2009 period under consideration. Moreover, the variables indicated can better explain future ratings of the best-rated banks, and also can better explain past ratings for the lowest-rated banks. This fact may indicate that rating agencies were more conservative when assigning ratings to low-rated banks and these were based on an analysis of historical accounting data. The main result of the conducted study is the lack of relation between bank ratings and financial leverage and capital adequacy. In addition, the relationship between banks' credit ratings and liquidity is the reciprocal of the expected relationship, with less liquid banks having the ratio of loans to customer deposits linked to higher ratings.

The purpose of credit derivatives is to protect against financial losses related to the risk of non-payment of debt. Typically, such an instrument is credit default swaps (CDS), a kind of bilateral contracts under which the buyer pays a periodic fee in exchange for a conditional payment of the counterparty in case of a credit event (Silva \& Wanderlei, 2015). Ötker-Robe and
Podpiera (2010) undertook to identify the basic variables that drive CDS in the initial phase of the crisis in large, complex European financial institutions (LCFI). Using the estimation of panel data, it was pointed out that LCFI business models, their earning potential and economic uncertainty expressed as market expectations regarding future risks related to individual LCFI and views on the outlook for economic growth are among the most important factors determining credit risk. The results of the authors' research are largely consistent with the results of literature studies on bankruptcy the determinants of which largely cover the entire CAMEL structure, i.e. capital adequacy, asset quality, management quality, profitability potential, liquidity and market risk sensitivity. The article also provides a potential vulnerabilitybased tool - LCFI early warning systems, by establishing the relationship between the financial and market condition of LCFI and its spread on CDS.

\section{Methodology}

\subsection{Data Description}

This paper attempts to examine the determinants which have an important impact on adequacy risk represented by the Tier I ratio in Central Eastern European commercial banks. The data came from the Thomson Reuters database. All data concerning ratios and variables have been taken and counted from the first quarter of 2007 to the last one of 2017. The analysis omitted some commercial banks from the analyzed countries due to gaps in the data (unbalanced panel). It is worth highlighting that the analyzed period covers the time of the global financial crisis, which could lead to unusual results. The study uses quarterly data (44 observations) and eight variables which represent commercial banks' financial ratios in the fields of the size of bank activity (SIZE - the natural logarithm of total assets), importance of equity (EQUITY - ratio of equity to total assets), credit risk (LOANCOSTS - allowances to total loans, LOANS - loans to total assets), quality of loans portfolio (NPL), profitability (ROE - return on equity ratio) and liquidity (LIQUIDITY - liquid assets to total assets, LTD - loans to deposits ratio). The article covers data taken from 202 
commercial banks from $16 \mathrm{CEE}$ countries such as: Bosnia and Herzegovina, Bulgaria, Croatia, the Czech Republic, Germany, Hungary, Lithuania, Macedonia, Poland, Montenegro, Serbia, Romania, Russia, the Slovak Republic, Slovenia, and Ukraine.

In this paper, the TIER I ratio is Tier 1 Capital at the end of the fiscal interim to Total Risk-Weighted Assets for the same period and is expressed as a percentage. In accordance with Basel III, Tier 1 Common Equity includes: ordinary shares issued by the bank, stock premium including CET1, retained earnings, other cumulative comprehensive income and other reserves disclosed, ordinary shares issued by the consolidated subsidiaries of the bank and held by third parties, regulatory adjustments used in the CET1 calculations (BCBS, 2010). Banks are required to maintain an appropriate amount of capital through legal capital requirements, which is why the bank's capital should be at least at the level of minimum requirements. This statement is in line with Mishkin (2000), who claims that banks also have their capital because they are obliged to do so by supervisors and regulators. Due to the high cost of maintaining capital, bank managers often want to have smaller capital than required by supervisory regulations. Regulatory requirements generally mandate this ratio to exceed $4.5 \%$ (BCBS,2010).

SIZE of the bank is an important factor that affects the bank's capital and is related to the ownership structure of equity and access to equity. Research (Büyüksalvarcı \& Abdioğlu, 2011) shows that some banks want to maintain better ratings in order to maintain higher reserves and larger size, but larger banks can be found in which the ratio between the capital adequacy ratio and the size is negative. The author assumes that the relationship between the Tier 1 ratio and the bank's size, expressed as the natural logarithm of total assets, is positive. This can be explained by the need to maintain higher capital requirements in connection with expanding operations and undertaking more risky activities.

EQUITY is a ratio of equity to total assets. It is an indicator that shows how many percent of the balance sheet total the bank's own capital is. It is worth emphasizing that banks have a small percentage of equity in their structure because they largely raise capital from customers in the form of deposits. It is an indicator that measures the importance of equity in the bank's operations. A negative relationship between EQUITY (ratio of equity to total assets) and the TIER I ratio is expected because financing loans and banks' activities by equity is much safer than financing them by clients' deposits so there is no need to maintain a higher level of safe Tier 1 capitals.

LOANSCOSTS is a ratio of allowances to total loans. This indicator shows what proportion of all loans are granted allowances for credit losses. This indicator is used to describe the quality of the bank's loan portfolio. Its high values mean a bad credit policy of the bank and are associated with a high credit risk of the borrowers. This index is also a measure of credit activity costs because making new allowances in banks means increasing the level of banks' costs of loans. A negative relationship between LOANCOSTS (allowances to total loans) and the TIER I ratio is expected because these banks which hold a higher level of capitals are expected to have a lower level of loans allowances as a result of covering losses by equity.

NPL is a ratio of non-performing loans to total loans. The NPL indicator reflects the quality of the bank's loan portfolio. This indicator is a kind of measurement of credit risk and default risk of the bank's clients. In this study, the non-performing loans ratio is the value of "doubtful" loans to the nominal value of total loans. Banks with a high NPL are considered very risky. NPL is a loan that the borrower does not plan to pay within 90 days. In their study, Shrieves and Dahl (1992) use non-working assets and the ratio of risk-weighted assets to total assets. Ediz et al. (1998) use the ratio of very risky assets to all risky assets to reflect the bank's exposure to risk, while Berger (1995) and Jacques and Nigro (1997) use the ratio of risk-weighted assets to total assets according to the Basel Accord framework. It is expected that the relationship between the NPL ratio and the TIER I ratio is negative, which means that banks with a higher capital level are expected to have a lower NPL as a result of coverage of the loan losses by equity.

LOANS is a measure of loans to total assets. This indicator is used to analyze the directions of operations and sources of financing banking operations. The share 
of loans in the bank's total assets indicates the level of risk since lending of funds is associated with a certain level of risk of the borrower. Therefore, a bank that has more risky assets should have better equity coverage. In addition, the higher the share of loans in assets, the lower the share of tangible assets and the higher the risk that the money lent will not be repaid (Kamran et al., 2014). The author expects a positive relationship between the TIER I ratio and the LOANS ratio because the more loans a bank has in its balance sheet, the riskier it becomes and the higher capital level it needs to keep.

ROE ratio (return on equity ratio) is a kind of profitability indicator which refers to the amount of net profit in relation to the total amount of equity (Athanasoglou et al., 2005). The ROE ratio is often used by shareholders to evaluate their investments. The company that is characterized by a high return on equity generates better profits. ROE is net income after tax divided by the total equity capital (Khrawish, 2011), which represents the rate of return obtained by the bank's shareholders. Thus, the higher the ROE, the more effective the management of shareholders' capital (Oloo, 2010).

LIQUIDITY is a ratio of liquid assets to total assets. The liquidity risk at the bank is the result of the bank's inability to meet its obligations. The liquidity risk increases when banks cannot forecast demand for loans or deposits withdrawal, accompanied by the inability to acquire new sources of money to cover that demand (Abdelkareem \& Salah, 2007). This indicator is aimed at determining the liquidity risk in a bank. Liquid assets are represented by cash in hand and at the central bank and cash in other banks or financial institutions. There is an inverse relationship between liquidity risk and the degree of capital adequacy (Heffernan, 1996).

LTD is the loans to deposits ratio. This indicator is used to assess the bank's liquidity. It is expected that the ratio between the loans to deposits ratio and the capital adequacy ratio will be positive because a high level of LTD ratio means a higher liquidity risk, which should be offset by a higher level of capital. At the same time, a high level of LTD means higher profits for the bank and this is why commercial banks want to increase the level of that ratio.

\subsection{Methodology Description}

Regarding the fact that the data are both time series and cross-sectional data, it was decided not to analyze each bank separately and apply the panel regression method that would allow the determinants of solvency risk to be analyzed. To choose the better model between the fixed effect and random effect models, the Hausman test was performed. $\mathrm{H}_{0}$ for the Hausman test was that the random effect model is appropriate and the alternative hypothesis was that the fixed effect model is appropriate. The main purpose was to find out if a significant correlation between unobserved individual specific random effects and regressors exists. The results of the Hausman test $(\mathrm{H}=8.78315, \mathrm{p}=0.360918)$ proves that the null hypothesis is accepted by the analyzed data and the random effect model is preferred. A diagnostic test of the panel model was carried out in order to verify the Breusch-Pagan test. It served to assess the significance of the variance of the random component. As a result of the analysis, the value of Breusch-Pagan test $\mathrm{LM}=2772.63$ was obtained with the value of $p=0$. On this basis, it was justified to reject the null hypothesis in favor of the alternative hypothesis, which indicates a significant impact on variance of the individual effects introduced into the model. Therefore, the use of the CLS to estimate the model is not justified and it is necessary to find a different method of estimating the model. In order to assess the significance of individual effects in the tested model, the Wald test was carried out, which was to verify the zero hypothesis that the regression parameters for the variables used in the model are 0 , against the alternative hypothesis that the regression parameters are different from zero. The Wald test statistic was $F(8,1754)=8.48464$ with a value of $p=2.213 * 10-11$. Such results mean that it is reasonable to reject the null hypothesis for the alternative hypothesis. Thus, the regression parameters for the indicated variables in the model are different from zero. Thus, the panel regression model is written as:

TIER $I_{i, t}=\beta_{0}+\beta_{1} \mathrm{SIZE}_{i, t}+\beta_{2}$ EQUITY $_{i, t}$ $+\beta_{3}$ LOANCOSTS $_{i, t}+\beta_{4}$ NPL $_{i, t}+\beta_{5} \mathrm{LO}^{-}$ $\mathrm{ANS}_{i, t}+\beta_{6} \mathrm{ROE}_{i, t}+\beta_{7} \mathrm{LIQUIDITY}_{i, t}+$ $\beta_{8} \mathrm{LTD}_{i, t}+\varepsilon_{i}$ 
where:

TIER $I_{i, t}-$ common equity Tier I to riskweighted assets of bank $i$ at time $t, \mathrm{SIZE}_{i, t}$ - natural logarithm of total assets of bank $i$ at time $t, \mathrm{EQUITY}_{i, t}$ - equity to total assets of bank $i$ at time $t$, LOANCOSTS LO $_{i, t}$ - allowances to credits of bank $i$ at time $t, \mathrm{NPL}_{i, t}$ - non-performing loans to total credits of bank $i$ at time $t, \mathrm{LOANS}_{i, t}$ - loans to assets of bank $i$ at time $t, \mathrm{ROE}_{i, t}-$ return on equity of bank $i$ at time $t$, LIQUIDITY $_{i, t}$ - liquid assets to total assets of bank $i$ at time $t, \mathrm{LTD}_{i, t}$ - loans to deposits of bank $i$ at time $t, \beta_{0}$ - constant, $\varepsilon_{i}-$ residual error of regression.

\section{Empirical Results}

The main purpose for this study is to determinate statistically significant factors impacting the capital adequacy ratio represented by the Tier I ratio in commercial banks in Central Eastern Europe. For the research, 8 variables were chosen: natural logarithm of total assets, equity to total assets, credit allowances to loans, non-performing loans to total loans, loans to assets, return on equity, liquid assets to total assets, loans to deposits.

The main hypothesis for this research assumes that the natural logarithm of total assets, equity to total assets, credit allowances to loans, non-performing loans to total loans, loans to assets return on equity, liquid assets to total assets, loans to deposits have no significant impact on banks' Tier I ratios.

The set of independent variables chosen for the model was selected based on the study of the significance of variable correlations. The finally selected independent variables are characterized by a strong relationship with the dependent variable and no relationship between them.

Table 1 includes the main descriptive statistics of the chosen variables like: average, median, standard error, minimum and maximum.

Tab. 1. Descriptive statistics

\begin{tabular}{|l|c|c|c|c|c|}
\cline { 2 - 6 } \multicolumn{1}{c|}{} & AVERAGE & MEDIAN & STANDARD ERROR & MIN & MAX \\
\hline TIER I & 14.2300 & 12.6000 & 7.6890 & 2.4200 & 67.1500 \\
\hline SIZE & 21.3400 & 21.1900 & 2.3800 & 14.6500 & 28.4500 \\
\hline EQUITY & 0.0779 & 0.0314 & 0.1219 & -0.6265 & 1.2250 \\
\hline LOANCOSTS & 0.5587 & 0.9625 & 0.6028 & -5.8830 & 6.8800 \\
\hline NPL & 0.1074 & 0.0000 & 1.8590 & 0.0000 & 73.9100 \\
\hline LOANS & 0.3737 & 0.3845 & 0.2928 & 0.0000 & 0.9993 \\
\hline ROE & 0.0280 & 0.0000 & 0.1061 & -0.8094 & 0.7811 \\
\hline LIQUIDITY & 0.2463 & 0.1859 & 0.2334 & 0.0000 & 1.1370 \\
\hline LTD & 0.8802 & 0.8586 & 0.4408 & 0.0000 & 4.2290 \\
\hline
\end{tabular}

Source: Own elaboration.

The regression results of the random effect model are shown in Table 2. The dependent variable was the Tier I ratio (TIER I). The R-squared indicator of the random effect model was 0.800367 , which means that $80.04 \%$ of variability of the Tier I ratio can be explained by the variables chosen for the model. Table 2 shows also estimated coefficients. The regression proved that the variables: SIZE (the natural logarithm of total assets), LOANCOSTS (allowances to total loans), LIQUIDITY (liquid assets to total assets) and LTD (loans to deposits ratio) have no statistically significant impact on the TIER I ratio. 


\begin{tabular}{|l|c|c|}
\cline { 2 - 3 } \multicolumn{1}{c|}{} & COEFFICIENT & PROBABILITY \\
\hline CONSTANT & 15.3011 & 0.0000 \\
\hline SIZE & -0.0020 & 0.9763 \\
\hline EQUITY & 4.1609 & 0.0000 \\
\hline LOANCOSTS & -0.1437 & 0.4340 \\
\hline NPL & 0.0668 & 0.0128 \\
\hline LOANS & -1.2028 & 0.0008 \\
\hline ROE & 3.3378 & 0.0004 \\
\hline LIQUIDITY & 0.2054 & 0.6704 \\
\hline LTD & -0.8229 & 0.1113 \\
\hline
\end{tabular}

Source: Own elaboration.

The variable EQUITY (ratio of equity to total assets) has a significant and positive impact on the TIER I ratio, which can mean that these banks that have more equity have also a higher TIER I ratio. What is more, this relationship is strong. It seems logical because TIER I capitals are a part of equity capitals in commercial banks.

The variable NPL (non-performing loans to total loans) has a significant and positive impact on the TIER I ratio, which means that those banks that have a higher level of non-performing loans in their balance sheet also maintain a higher level of TIER I capital but it is worth highlighting that this relationship is quite weak. This relation occurs because non-performing loans are very risky and cost-intensive for banks, which is why they require maintaining a higher level of safe capitals.

The variable LOANS (loans to total assets) has a significant and negative impact on the TIER I ratio and this impact is quite strong. This means that commercial banks in Central and Eastern Europe run risky activities, and despite increasing their lending activity, they do not increase the level of safe TIER I capitals.

The variable ROE (return on equity ratio) has a significant, positive and strong impact on the TIER I ratio. That means that banks with higher profitability maintain higher TIER I capitals.

\section{Conclusion}

The main aim of this paper was to empirically find determinants that have an impact on capital adequacy risk represented by the Tier I ratio in commercial banks situated in Central Eastern Europe. In the study, secondary data were used from the Thomson Reuters database. The study covers 10 years, from 2007 to 2017. The panel data regression was used to analyze the relationship between the Tier I ratio and 8 variables such as: the size of the bank's activity (SIZE - the natural logarithm of total assets), the importance of equity (EQUITY - ratio of equity to total assets), credit risk (LOANCOSTS - allowances to total loans, LOANS - loans to total assets), quality of loans portfolio (NPL - non-performing loans to total loans), profitability (ROE - return on equity ratio) and liquidity (LIQUIDITY - liquid assets to total assets, LTD - loans to deposits ratio).

The regression which used random effects model showed that the natural logarithm of total assets, allowances to total loans, liquid assets to total assets and loans to deposits ratio have no statistically significant impact on the Tier I ratio. At the same time, variables: ratio of equity to total assets, non-performing loans to total loans and return on equity ratio have a statistically important and positive impact on the TIER I ratio; meanwhile, loans to total assets have a statistically significant but negative impact on the TIER I ratio.

The results of the study show that commercial banks in Central and Eastern Europe which maintain higher equity are less exposed to the risk of solvency. At the same time, the analyzed banks are cautious when it comes to non-performing loans. Their growing level in the balance sheet is a signal to maintain higher TIER I capitals, 
which results in a lower exposure to the risk of insolvency. At the same time, these banks which increase their profitability care about their solvency increasing the level of Tier 1 ratio. It is worth emphasizing that the analyzed banks, like all other companies, want to increase their profits. To do this, they expand their operations and provide more loans, thus increasing the level of credit risk. This action is not associated with an increase in stable and safe TIER I capitals because it is too high a cost for banks, and therefore this situation causes a risk of solvency.

\section{References}

Abusharba, M.T., Triyuwono, I., Ismail, M., \& Rahman A.F. (2013, March). Determinants of capital adequacy ratio (CAR) in Indonesian Islamic commercial banks. Global Review of Accounting and Finance, 4(1).

Ahmad, R., Ariff, M., \& Skully, M.J. (2008, December). The determinants of bank capital ratios in a developing economy. Asia-Pacific Financial Markets, 15(3-4).

Athanasoglou, P., Brissimis, S., \& Delis, M. (2005, June). Bank-specific, industry-specific and macroeconomic determinants of bank profitability (Working Paper No. 25). Published in RePEc.

BCBS. (2010). Basel III: A global regulatory framework for more resilient banks and banking system.

Bellotti, T., Matousek, R., \& Stewart, C. (2011, April). Are rating agencies' assignments opaque? Evidence from international banks. Expert Systems with Applications, 38(4).

Berger, A.N., \& Udell, G.F. (1994). Did risk-based capital allocate bank credit and cause a "credit crunch" in the United States?. Journal of Money, Credit and Banking, 26.

Büyüksalvarcı, A., \& Abdioğlu, H. (2011). Determinants of capital adequacy ratio in Turkish banks: A panel data analysis. African Journal of Business Management. 5(27).

Cox, R.A.K., \& Wang, G.W.Y. (2014). Predicting the US bank failure: A discriminant analysis. Economic Analysis and Policy, (44).

Dreca, N. (2014, October). Determinants of capital adequacy ratio in selected Bosnian banks. Dumlupinar University Journal of Social Sciences, XIV.

Ediz, T., Michael, I., \& Perraudin, W. (1998). The impact of capital adequacy standards on UK bank behaviour. Economic Policy Review, 4. Federal Reserve Bank of New York.

Heffernan, S. (1996). Modern banking in theory and practice. England: John Wiley \& Sons Ltd.
Hassan, O.A.G, \& Barrell, R. (2013). Accounting for the determinants of banks' credit ratings. Brunel University of London Economics and Finance Working Paper Series, 13-02.

Hau, H., Langfield, S., \& Marques-Ibanez, D. (2012, October). Bank ratings: What determines their quality?. EBC Working Paper Series, 1484.

Iwanicz-Drozdowska, M. (2017). Zarzadzanie ryzykiem bankowym. Warszawa: Poltext.

Jacques, K., \& Nigro, P. (1997). Risk-based capital, portfolio risk, and bank capital: A simultaneous equations approach. Journal of Economics and Business, 49.

Khrawish, A. (2011). Determinants of commercial banks performance: Evidence from Jordan. International Research Journal of Finance and Economics. Zarqa University.

Klepczarek, E. (2015). Determinants of European banks' capital adequacy. Comparative Economic Research, 18(4).

López-Iturriaga, F.J., López-de-Foronda, O., \& Sanz, I.P. (2010). Predicting bankruptcy using neural networks in the current financial crisis: A study of U.S. commercial banks. University of Burgos Working Papers.

Małecki, W. (2014). Regulacje sektora bankowego. Prace i materiaty Instytutu Rozwoju Gospodarczego: No. 94. Polityka gospodarcza jako gra w wyzwania i odpowiedzi rozwojowe. Szkoła Główna Handlowa.

Mishkin, F. (2000). The economics of money, banking and financial markets ( $6^{\text {th }}$ ed.). New York: Addison Wesley.

Nieborak, T. (2001). Realizacja zaleceń Komitetu Bazylejskiego ds. nadzoru bankowego dotyczących procesu powstawania i funkcjonowania banku w polskim prawie bankowym. Ruch Prawniczy, Ekonomiczny i Socjologiczny, (1-2).

Oloo, O. (2010). Banking survey report, the best banks this decade 2000-2009. Kenya: Think Business Limited.

Ötker-Robe, I., \& Podpiera, J. (2010). The fundamental determinants of credit default risk for european large complex financial institutions (IMF Working Paper No. WP/10/153).

Shingjergji, A., \& Hyseni, M. (2015, January). The determinants of the capital adequacy ratio in the Albanian banking system during 2007-2014. International Journal of Economics, Commerce and Management, $\operatorname{III}(1)$.

Shrieves, R., \& Dahl, D. (1992). The relationship between risk and capital in commercial banks. Journal of Banking \& Finance, 16, 439-457.

Sikorzewski, W. (2011). Założenia, konsekwencje i mankamenty. Bank, (2). 
Silva, E.O., \& Wanderlei, L.P. (2015). Determinants of sovereign CDS spreads: Evidence from Brazil. International Business Research, 8(7).

Thlon, M. (20018). Świetność i upadek. Historia banku Lehman Brothers. Gazeta Bankowa, (42).

Yuanjuan, L., \& Shishun, X. (2012). Effectiveness of China's commercial banks' capital adequacy ratio regulation. A case study of the listed banks. Interdisciplinary Journal of Contemporary Research Business, 4(1).

Żółtkowski, W. (2007). Zarzadzanie ryzykiem bankowym w praktyce. Warszawa: CeDeWu.pl.

http://tradersarea.pl/dlaczego-upadl-lehman-brothers/. Retrieved on 28 December 2018. 